\title{
A new species of Hormathia (Actiniaria, Hormathiidae) from the eastern Weddell Sea, Antarctica
}

Received: 22 September 2000 / Received in revised form: 27 December 2000

Accepted: 28 February 2001 / Published online: 25 April 2001

(C) Springer-Verlag and AWI 2001

\begin{abstract}
A new species of sea anemone in the genus Hormathia, is described and illustrated based on fortytwo specimens collected during the Polarstern cruises ANT XV/3 and ANT XVII/3 in the Weddell Sea. The main features of the new taxon are the crown of flattened and hooked tubercles at the distal end of the scapus, the regular arrangement of pointed tubercles along the column and the cnidom. The new species shares the pointed tubercles, at least in the upper part of the scapus, with two other species of Hormathia in the southern hemisphere: Hormathia spinosa Hertwig 1882 and H. pectinata Hertwig 1882
\end{abstract}

Keywords Hormathia spp. Sea anemone - Weddell Sea

\section{Introduction}

A large collection of more than 1400 specimens of sea anemones was collected during the recent EASIZ II and EASIZ III (Ecology of Antarctic Sea Ice Zone) Polarstern cruises to the Weddell Sea and Antarctic Peninsula. From this collection, 42 specimens of an undescribed species of the genus Hormathia Gosse 1859 were detected. This species is described, and compared to the type material of its most similar congeners, $H$. spinosa Hertwig 1882 and $H$. pectinata Hertwig 1882.

According to Fautin \& Barber (1999), Hormathiidae is one of the richest families of deep-sea anemones. The family is represented in the Antarctic waters by a number of species, with H. lacunifera (Stepheson 1918) as the most dominant Antarctic sea anemone (Fautin-Dunn 1983).

Communicated by: H.-D. Franke

E. Rodríguez (৫) · P. J. López-González

Laboratorio de Biología Marina, Facultad de Biología,

Universidad de Sevilla, Reina Mercedes 6, 41012, Sevilla, Spain

e-mail: fani@cica.es

Tel.: +34 954557100, Fax: +34954233480
The genus Hormathia is one of the most distinctive genera of the Hormathiidae. It is characterized by 6 pairs of perfect and sterile mesenteries, and a similar number of mesenteries distally and proximally. The column is divisible into scapus and scapulus. The scapus is covered by a cuticle and provided with tubercles that may be arranged in rows. There are no cinclides, and there are never more than 96 tentacles (without thickenings on their aboral side),nor a cup-like pedal disc (Carlgren 1949; Manuel 1988; Tur 1993). Despite these characteristics, the variability between Hormathia species is high (Stephenson 1935; Riemann-Zürneck 1973, 1994; Grebelnyi 1980a, 1980b). Thus, the description of diagnostic characters for identifying the species ascribed to this genus have not been always satisfactory, resulting in many synonyms in the literature (see for example synonyms for $H$. lacunifera given by Fautin-Dunn 1983: 50). Incomplete descriptions or the examination of a few, if not single, specimens to propose a new species, creates mistakes. Therefore, the re-examination of the type material or recently collected specimens from the type locality are essential.

McMurrich (1893) proposed the genus Chitonanthus for those hormathiid species in which the scapulus bears longitudinal ridges and the scapus shows strong pointed tubercles not arranged in any definite order, particularly in its distal portion. He reserved the genus Hormathia for those forms with a smooth scapulus and only a coronal row of tubercles. McMurrich (1893: 189) included Phellia pectinata Hertwig 1882, P. spinifera Hertwig 1888 , and $H$. andersoni Haddon 1888, within the genus Chitonanthus. Nevertheless, he expressed doubts about the generic diagnostic utility of the arrangement of these tubercles. According to Stephenson (1920: 512), the presence of capitular ridges should not be used as a generic character in hormathiids. Some genera such as Chitonanthus, Chondractinia Lütken 1860 and Chitonactis Fischer 1874, that were separated in the past by capitular features, are now considered synonyms of the genus Hormathia, using the diagnostic characters cited above (see Carlgren, 1949). 
According to Fautin-Dunn (1983:54), six Hormathia species are currently recognisable in the southern hemisphere: H. spinosa, H. pectinata, H. castanea (McMurrich 1904), H. lacunifera, H. georgiana Carlgren 1927 and H. bouvetensis Carlgren 1928 (see Hertwig 1882a, 1882b; McMurrich 1904; Stephenson 1918; Carlgren 1927, 1928). Among these, only H. pectinata and H. spinosa share the character of pointed tubercles in the scapus with the new species here described.

\section{Material and methods}

The material studied was collected on the Polarstern cruises ANT XV/3 (EASIZ II) and ANT XVII/3 (EASIZ III), during the austral summer of 1998 and 2000, respectively, to the eastern Weddell Sea and Antarctic Peninsula.

Sea anemones were relaxed using menthol crystals and subsequently fixed in $10 \%$ formalin in seawater. Fragments of selected specimens were dehydrated in buthanol (Johansen 1940), and embedded in paraffin. Histological sections 6-10 $\mu \mathrm{m}$ thick were stained with Ramón and Cajal's Triple Stain (Gabe 1968).

Cnidom measurements were taken from capsules in squash preparations at $1000 \mathrm{X}$ magnification on a Nomarski interference contrast microscope. Despite frequencies given being subjective impressions based on squash preparations, they do give some idea of the relative abundance of the various types, varieties, and sizeclasses.

Specimens of the species studied in this article have been deposited in the Zoologisches Institut und Zoologisches Museum in Hamburg (ZMH), the Laboratorio de Biología Marina of the University of Seville in Spain (LBM), the Natural History Museum in London (NHM), the Nationaal Natuurhistorisch Museum, formerly the Rijksmuseum van Natuurlijke Historie, in Leiden (RMNH), and the Swedish Museum of Natural History in Stockholm (SMNH).

For purposes of comparison, the following material deposited at the NHM was also examined:

- Cereus spinosus Hertwig 1882 (NHM 1890.7.23.1). Syntype: Challenger cruise, stn. $157,53^{\circ} 55^{\prime} \mathrm{S} 108^{\circ} 35^{\prime} \mathrm{E}, 1950$ fathoms, 3 March 1874. This species is now ascribed to the genus Hormathia, as H. spinosa (Hertwig 1882) (see Carlgren 1949).

Remarks: Hertwig (1882a, 1882b) included as material examined for the description of his Cereus spinosus specimens from two widely separated stations, 157 and 237, from the Challenger Expedition. According to the biogeographical areas proposed by Longhurst (1998), the former station could be considered as
SANT (Subantarctic Water Ring Province, off South Australia), while the latter one is included in KURO (Kuroshio Current Province, off East Japan). Our comparisons with the new species here described are based on the subantarctic material (stn 157) first mentioned in Hertwig's monograph. The Challenger stations are remarkably far apart, but the material is from the bathyal zone, where wide distributions are often recorded. Despite this, a comparative study based on this material is desirable to corroborate the distribution of $H$. spinosa, or split this material in two different species.

- Phellia pectinata Hertwig 1882 (NHM 1889.11.25.18). Type: Challenger cruise, stn. $307,4^{\circ} 24^{\prime} \mathrm{S} 74^{\circ} 23^{\prime} \mathrm{W}, 147$ fathoms, 4 January 1876 . This species is now ascribed to the genus Hormathia, as $H$. pectinata (Hertwig 1882) (see Carlgren 1949).

\section{Results}

- Order Actiniaria Hertwig, 1882

- Family Hormathiidae Carlgren, 1925

- Genus Hormathia Gosse, 1859

\section{Hormathia armata sp. nov}

Figs. 1, 2, 3, 4, 5, Table 1.

Type Material Holotype: ZMH (C 11656), 1 specimen, Polarstern ANT XV/3, stn. 48/071, eastern Weddell Sea, 7049.3’S 10²8.6'W, 281-301 m depth, 1 Feb 1998, bottom trawl. Paratypes: ZMH (C 11657), 3 specimens, Polarstern ANT XV/3, stn. 48/189, eastern Weddell Sea, 71'40.2'S $12^{\circ} 43.6^{\prime} \mathrm{W}, 244-248 \mathrm{~m}$ depth, 15 Feb 1998, Agassiz trawl; ZMH (C 11658), 2 specimens, Polarstern ANT XV/3, stn. 48/222, eastern Weddell Sea, 7050.6'S $10^{\circ} 35.5^{\prime} \mathrm{W}, 234-267 \mathrm{~m}$ depth, 19 Feb 1998, bottom trawl; LBM (ANT-201), 1 specimen, Polarstern ANT XVII/3, stn. 119.1, eastern Weddell Sea, 7050.40'S $10^{\circ} 35.20^{\prime} \mathrm{W}, 226-266 \mathrm{~m}$ depth, 7 Apr 2000, bottom trawl; NHM (2000.2907), 1 specimen, Polarstern ANT XVII/3, stn. 119.1, eastern Weddell Sea, $70^{\circ} 50.40$ 'S $10^{\circ} 35.20^{\prime} \mathrm{W}, 226-266 \mathrm{~m}$ depth, 7 Apr 2000, bottom trawl; RMNH (Coel. 24700), 1 specimen, Polarstern ANT XVII/3, stn. 119.1, eastern Weddell Sea, $70^{\circ} 50.40^{\prime} \mathrm{S} 10^{\circ} 35.20^{\prime} \mathrm{W}, 226-266 \mathrm{~m}$ depth, 7 Apr 2000,
Fig. 1 Hormathia armata sp. nov. Living specimen after menthol anaesthesia. (A) Oral disc; notice the white V-shaped marks at the bases of the fourth cycle of tentacles. (B) Distal portion in lateral view; notice the flattened and hook-like pointed tubercles (white arrow); notice the small white marks at base on aboral side of the tentacles of the last cycles (black arrows). Scale bars: $20 \mathrm{~mm}$
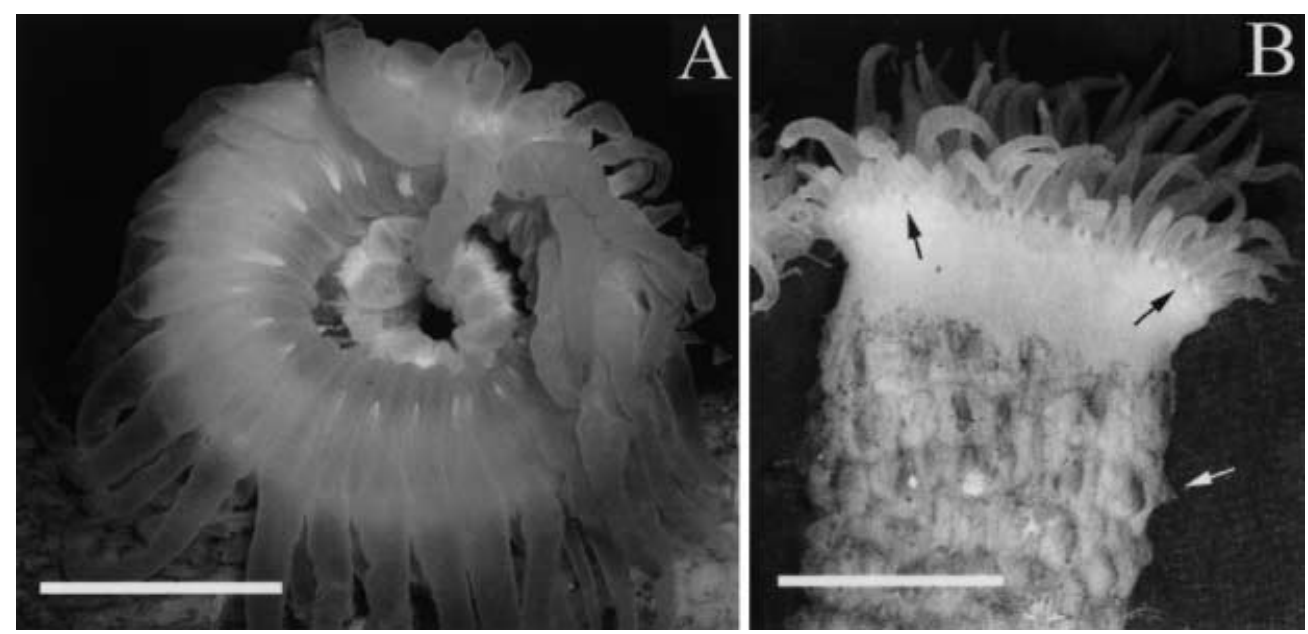
Fig. 2 Hormathia armata sp. nov. (A) Holotype (ZMH C 11656) in lateral view. White arrow indicates the flattened and hook-like pointed tubercles. (B) Paratype (ZMH C 11657) in oral view. (C) Paratypes (ZMH C 11657). Scale bars: $30 \mathrm{~mm}$
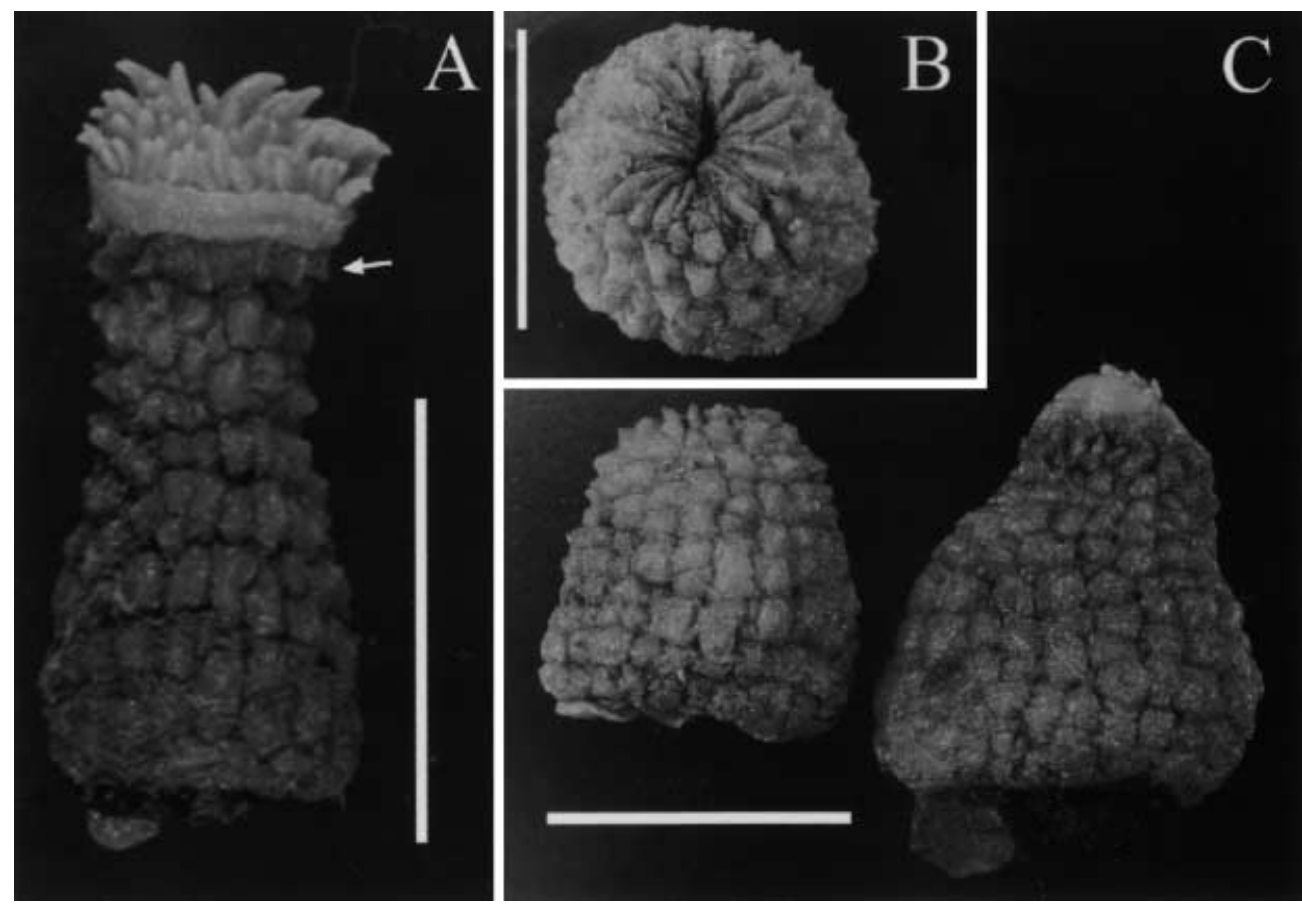

Fig. 3 Hormathia armata sp. nov. (A) Detail of the flattened and hook-like pointed tubercles from the holotype $(\mathrm{ZMH}$ C 11656). (B) Part of the crown of flatted and pointed pyramidal tubercles with square-shaped bases from the paratype (ZMH C 11657). Scale bars: A, $3 \mathrm{~mm}$; $\mathrm{B}, 5 \mathrm{~mm}$
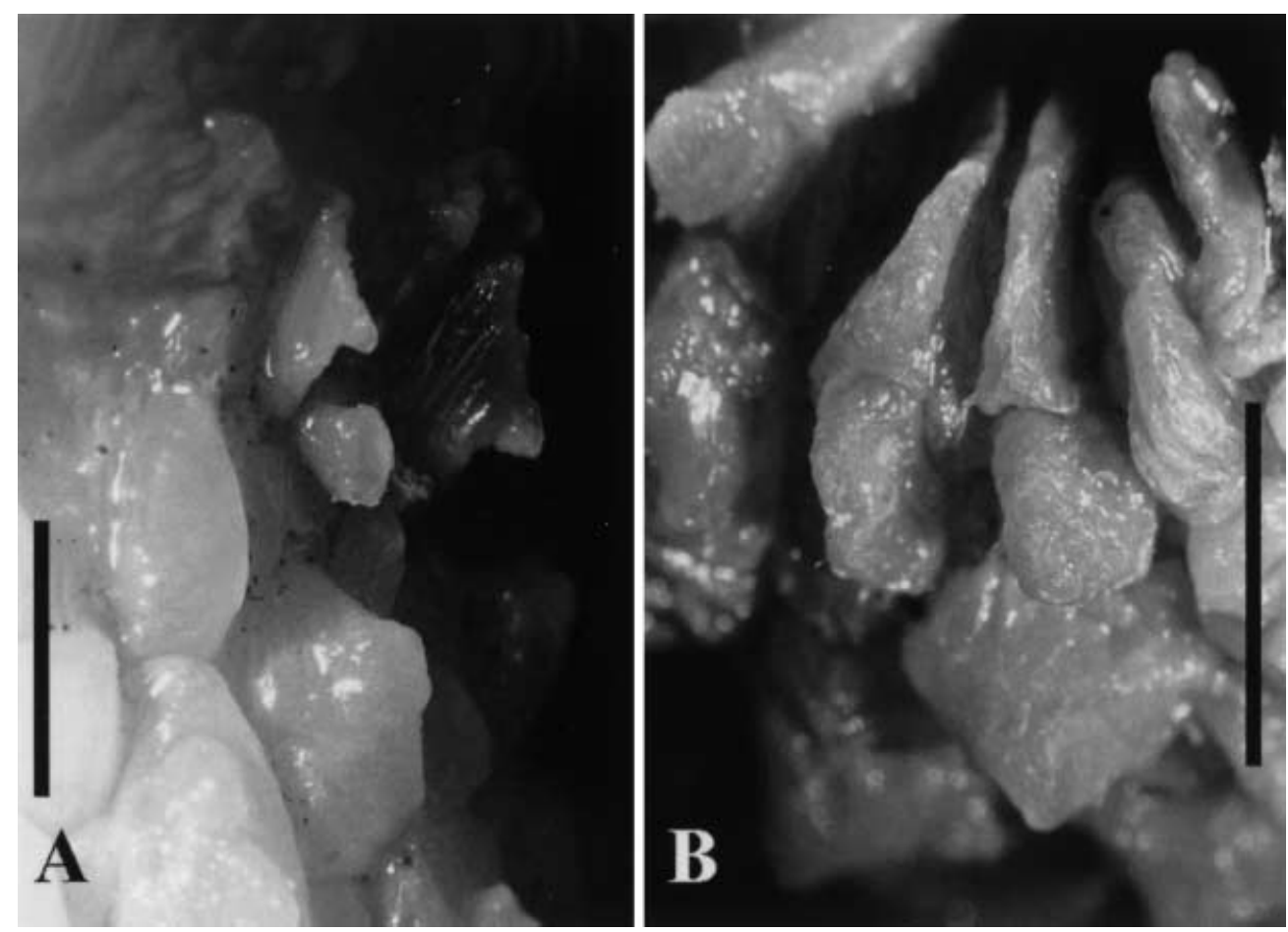

bottom trawl; SMNH (Type $\mathrm{n}^{\circ}$ 5263), 2 specimens, Polarstern ANT XVII/3, stn. 119.1, eastern Weddell Sea, 7050.40’ S 10³5.20’W, 226-266 m depth, 7 Apr 2000, bottom trawl.

Additional Material LBM (ANT-195), 1 specimen, Polarstern ANT XV/3, stn. 48/209, eastern Weddell

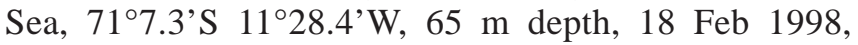
TVgrab; LBM (ANT-196), 2 specimens, Polarstern ANT XV/3, stn. 48/220, eastern Weddell Sea,
7050.4'S 10³5.4'W, 236-272 m depth, 19 Feb 1998 , bottom trawl; LBM (ANT-197), 1 specimen, Polarstern ANT XVII/3, stn. 111.7, eastern Weddell Sea, 71 ${ }^{\circ} 07.50^{\prime} \mathrm{S} 11^{\circ} 27.70^{\prime} \mathrm{W}, 67-68 \mathrm{~m}$ depth, 5 Apr 2000, TVgrab; LBM (ANT-198), 1 specimen, Polarstern ANT XVII/3, stn. 111.18, eastern Weddell Sea,

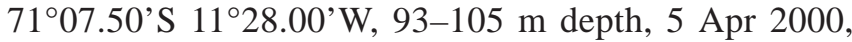
TVgrab; LBM (ANT-199), 1 specimen, Polarstern ANT XVII/3, stn. 111.18, eastern Weddell Sea, 
Fig. 4 Hormathia armata sp. nov. (ZMH C 11657).

(A) Cross section through mesenteries at stomodaeum level; notice the gonads on third and fourth cycle of mesenteries. (*) indicates endocoel between directive mesenteries, $(* *)$ indicates endocoel between mesenteries of second cycle. (B) Longitudinal section through mesogloeal marginal sphincter; margin at top of the picture. (C) Detail of section through mesogloeal marginal sphincter. Scale bars: A, $2 \mathrm{~mm}$; $\mathrm{B}, 1.5 \mathrm{~mm}$; $\mathrm{C}, 0.6 \mathrm{~mm}$
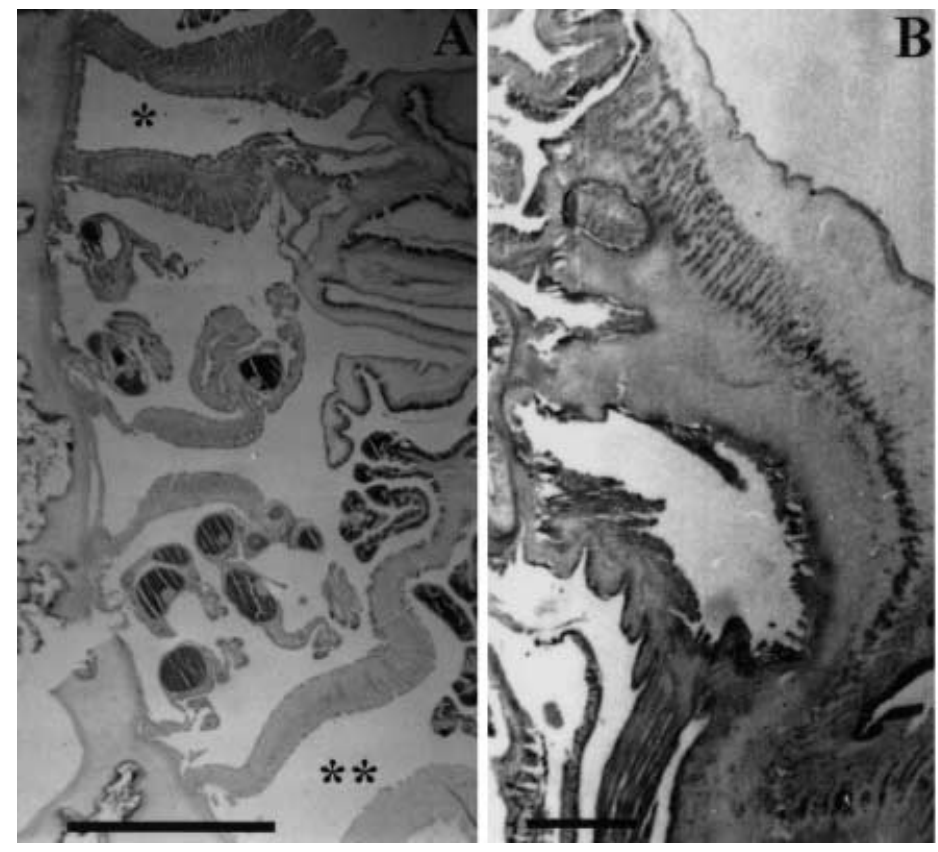

7107.50'S $11^{\circ} 28.00^{\prime} \mathrm{W}, 93-105 \mathrm{~m}$ depth, $5 \mathrm{Apr}$ 2000,TVgrab; LBM (ANT-200), 7 specimens, Polarstern ANT XVII/3, stn. 119.1, eastern Weddell Sea, 70 50.40'S 10³5.20’W, 226-266 m depth, 7 Apr 2000, bottom trawl; LBM (ANT-202), 2 specimens, Polarstern ANT XVII/3, stn. 119.1, eastern Weddell Sea, 70 50.40 'S $10^{\circ} 35.20^{\prime} \mathrm{W}, 226-266 \mathrm{~m}$ depth, 7 Apr 2000, bottom trawl; LBM (ANT-203), 1 specimen, Polarstern ANT XVII/3, stn. 119.1, eastern Weddell Sea, 70 $50.40 ’ \mathrm{~S} 10^{\circ} 35.20^{\prime} \mathrm{W}, 226-266 \mathrm{~m}$ depth, 7 Apr 2000, bottom trawl; LBM (ANT-204), 1 specimen, Polarstern ANT XVII/3, stn. 119.1, eastern Weddell Sea, 70 $50.40 ’ \mathrm{~S} 10^{\circ} 35.20^{\prime} \mathrm{W}, 226-266 \mathrm{~m}$ depth, 7 Apr 2000, bottom trawl; LBM (ANT-205), 1 specimen, Polarstern ANT XVII/3, stn. 122-2, eastern Weddell Sea, 70 $50.70^{\prime} \mathrm{S} 10^{\circ} 35.00^{\prime} \mathrm{W}, 233 \mathrm{~m}$ depth, 9 Apr 2000, TVgrab; LBM (ANT-206), 2 specimens, Polarstern ANT XVII/3, stn. 124-1, eastern Weddell Sea, 70 $50.60 ' \mathrm{~S} 10^{\circ} 35.40^{\prime} \mathrm{W}, 247-269 \mathrm{~m}$ depth, 9 Apr 2000, bottom trawl; NHM (2000.2908-2909), 2 specimens, Polarstern ANT XV/3, stn. 48/050, eastern Weddell Sea, 70 51.6'S $10^{\circ} 24.3^{\prime} \mathrm{W}, 282-283 \mathrm{~m}$ depth, $30 \mathrm{Jan}$ 1998, small bottom sampling gear; NHM (2000.2910 2911), 2 specimens, Polarstern ANT XV/3, stn. 48/100, eastern Weddell Sea, 73 $36.4^{\prime} \mathrm{S} 22^{\circ} 7.0^{\prime} \mathrm{W}, 440-444 \mathrm{~m}$ depth, 5 Feb 1998, bottom trawl; RMNH (Coel 24699), 4 specimens, Polarstern ANT XVII/3, stn. 119.1, eastern Weddell Sea, 70 $50.40^{\prime} \mathrm{S} 10^{\circ} 35.20^{\prime} \mathrm{W}, 226-266 \mathrm{~m}$ depth, 7 Apr 2000, bottom trawl; SMNH (General coll., n 30621), 1 specimen, Polarstern ANT XV/3, stn. 48/050, eastern Weddell Sea, 7051.6'S 10²4.3'W, 282-283 m depth, 30 Jan 1998, small bottom sampling gear; SMNH (General coll., $\left.\mathrm{n}^{\circ} 30620\right), 2$ specimens, Polarstern ANT XV/3, stn. 48/194, eastern Weddell Sea, 71'14.1'S $12^{\circ} 27.7^{\prime} \mathrm{W}, 244-246$ m depth, 16 Feb 1998, Agassiz trawl.
External anatomy Pedal disc to $40 \mathrm{~mm}$ diameter, well developed, 0.37-0.66 mm thick, broader than scapus. No mesenterial insertion visible. Slightly concave and commonly attached to rocks (Figs. 1, 2, 3).

Column thick and tough divided into scapus and scapulus. Scapus conical to globose in retracted specimens, cylindrical in expanded ones; to $30 \mathrm{~mm}$ diameter, $80 \mathrm{~mm}$ height in preserved specimens. Scapus tuberculate, with longitudinal and transverse ridges; tubercles almost rectangular (about 4-3.5 $\mathrm{mm}$ ) in proximal half, pyramidal and pointed in distal half, becoming flattened and pointed at distal end of scapus. Twelve ridges beginning on distal part of the scapus constitute a crown of flattened and hooked tubercles. Scapus with well-developed brownish, thin cuticle. Scapulus about $6 \mathrm{~mm}$ height, smooth.

Oral disc flat, wider in diameter than base in living specimens, usually retracted in preserved ones. Mouth on a cone. Tentacles cover most of oral disc. Tentacles smooth, as long as diameter of oral disc in living specimens, pointed and short in preserved ones. Inner tentacles longer than outer ones, to 96 in number, arranged in 5 cycles $(6+6+12+24+48)$.

Internal anatomy. Equal number of mesenteries distally and proximally. Mesenteries arranged hexamerously in four regular cycles: first cycle perfect and sterile; second and third cycles well developed, imperfect; fourth cycle poorly developed. Two pairs of directives connected with two well-developed siphonoglyphs. Gonads well developed on second, third, and fourth cycles in specimens collected in February; dioecious (Fig. 4).

Acontia few and coiled. Parietobasilar muscles well developed but without detached pennon. Retractor muscle diffuse and strong. Basilar muscles well developed with detached pennons. Mesogloeal marginal sphincter moderately strong, diffuse and long, transversely strati- 
Table 1 Hormathia armata nov. sp. Size ranges of the cnidae (in $\mu \mathrm{m}$ ) from four specimens, each one from the following lots: A = Holotype (ZMH C 11656); B = NHM (2000.2910-2911);
$\mathrm{C}=\mathrm{SMNH}$ (general coll., n0 30621); D = Paratype $(\mathrm{ZMH}$ C 11657). Frequency: $+++=$ very common, $++=$ common, $+=$ rather common, $--=$ sporadic. $\mathrm{N}=$ number of capsules measured.

\begin{tabular}{|c|c|c|c|c|c|}
\hline Body part & Nematocyst Type & Lot & $\begin{array}{l}\text { Range (in parentheses) of length and } \\
\text { width of nematocyst capsules in } \mu \mathrm{m}\end{array}$ & $\mathrm{N}$ & Frequency \\
\hline Pedal disc & Basitrichs 2 (B) & $\begin{array}{l}\text { A } \\
\text { B } \\
\text { C } \\
\text { D }\end{array}$ & $\begin{array}{l}(19.7-27.1) \times 3.3 \\
(21.3-27.1) \times 3.3 \\
(20.5-26.2) \times 3.3 \\
(22.9-28.7) \times(3.3-4.1)\end{array}$ & $\begin{array}{l}20 \\
20 \\
20 \\
20\end{array}$ & $\begin{array}{l}++ \\
+/++ \\
+/++ \\
++\end{array}$ \\
\hline Scapus & Basitrichs 2 (B) & $\begin{array}{l}\text { A } \\
\text { B } \\
\text { C } \\
\text { D }\end{array}$ & $\begin{array}{l}(18.0-22.0) \times(3.3-4.1) \\
(18.9-22.1) \times 3.3 \\
(17.2-22.1) \times 3.3 \\
(20.5-23.8) \times(3.3-4.1)\end{array}$ & $\begin{array}{r}16 \\
10 \\
10 \\
7\end{array}$ & $\begin{array}{l}+ \\
+ \\
+ \\
+\end{array}$ \\
\hline \multirow[t]{2}{*}{ Scapulus } & $\begin{array}{l}\text { Basitrichs } 2 \text { (B) } \\
\text { Microbasic }\end{array}$ & $\begin{array}{l}\text { A } \\
\text { B } \\
\text { C } \\
\text { D } \\
\text { A }\end{array}$ & $\begin{array}{l}(23.8-29.5) \times(3.3-4.1) \\
(18.9-28.7) \times(2.5-4.1) \\
(21.3-26.2) \times(3.3-4.1) \\
(24.6-29.5) \times(3.3-4.1) \\
-----\end{array}$ & $\begin{array}{l}20 \\
20 \\
20 \\
20\end{array}$ & $\begin{array}{l}++/+++ \\
++ \\
++ \\
++\end{array}$ \\
\hline & p-mastigophores $2(\mathrm{~F})$ & $\begin{array}{l}\mathrm{B} \\
\mathrm{C} \\
\mathrm{D}\end{array}$ & $\begin{array}{l}(20.5-23.8) \times(3.3-4.9) \\
----- \\
-----\end{array}$ & 15 & + \\
\hline Tentacles & $\begin{array}{l}\text { Spirocysts (A) } \\
\text { Basitrichs } 2 \text { (B) }\end{array}$ & $\begin{array}{l}\text { A } \\
\text { B } \\
\text { C } \\
\text { D } \\
\text { A } \\
\text { B } \\
\text { C } \\
\text { D }\end{array}$ & $\begin{array}{l}(28.7-46.3) \times(3.3-5.7) \\
(22.1-38.5) \times(3.3-5.7) \\
(26.2-45.1) \times(3.3-5.7) \\
(26.2-41.0) \times(3.3-4.9) \\
(23.9-31.2) \times(3.3-4.1) \\
(22.1-30.3) \times(2.5-3.3) \\
(26.2-31.2) \times 3.3 \\
(22.1-28.7) \times(2.5-3.3)\end{array}$ & $\begin{array}{l}20 \\
20 \\
20 \\
26 \\
20 \\
20 \\
20 \\
20\end{array}$ & $\begin{array}{l}+++ \\
+++ \\
+++ \\
+++ \\
++/+++ \\
++ \\
++ \\
++/+++\end{array}$ \\
\hline Stomodaeum & $\begin{array}{l}\text { Basitrichs } 1(\mathrm{D}) \\
\text { Microbasic } \\
\text { p-mastigophores } 1(\mathrm{E})\end{array}$ & $\begin{array}{l}\text { A } \\
\text { B } \\
\text { C } \\
\text { D } \\
\text { A } \\
\text { B } \\
\text { C } \\
\text { D }\end{array}$ & $\begin{array}{l}(30.2-38.5) \times(3.3-4.1) \\
(23.0-38.5) \times(3.3-4.9) \\
(30.3-41.8) \times(3.3-4.1) \\
(27.9-33.6) \times(3.3-4.1) \\
(30.2-38.4) \times(4.9-5.7) \\
(32.8-38.5) \times(3.3-5.7) \\
(27.9-36.1) \times(4.1-5.7) \\
(26.2-37.7) \times(4.9-6.6)\end{array}$ & $\begin{array}{l}20 \\
20 \\
20 \\
20 \\
20 \\
20 \\
20 \\
20\end{array}$ & $\begin{array}{l}++/+++ \\
++ \\
++/+++ \\
++ \\
++ \\
++ \\
++ \\
++\end{array}$ \\
\hline \multirow[t]{2}{*}{ Filaments } & Basitrichs 1 (D) & $\begin{array}{l}\text { A } \\
\text { B } \\
\text { C } \\
\text { D }\end{array}$ & $\begin{array}{l}(38.4-46.7) \times(4.1-4.9) \\
(27.9-54.9) \times(2.5-4.9) \\
(42.6-49.2) \times(4.1-5.7) \\
(37.7-50.0) \times(4.1-5.7)\end{array}$ & $\begin{array}{l}20 \\
20 \\
20 \\
20\end{array}$ & $\begin{array}{l}+ \\
++ \\
++ \\
+\end{array}$ \\
\hline & $\begin{array}{l}\text { Basitrichs } 3(\mathrm{C}) \\
\text { Microbasic } \\
\text { p-mastigophores } 2(\mathrm{~F})\end{array}$ & $\begin{array}{l}\text { A } \\
\text { B } \\
\text { C } \\
\text { D } \\
\text { A } \\
\text { B } \\
\text { C } \\
\text { D }\end{array}$ & $\begin{array}{l}(13.8-20.5) \times(1.6-2.5) \\
(13.9-17.2) \times(2.5-3.3) \\
(16.4-18.0) \times 2.5 \\
(13.1-18.0) \times(1.6-2.5) \\
(23.0-28.7) \times(3.3-4.9) \\
(22.1-27.9) \times(4.1-4.9) \\
(22.1-28.7) \times(4.1-4.9) \\
(20.5-27.9) \times(4.1-4.9)\end{array}$ & $\begin{array}{r}15 \\
8 \\
7 \\
7 \\
20 \\
17 \\
20 \\
20\end{array}$ & $\begin{array}{l}+ \\
+ \\
+ \\
+ \\
+/++ \\
+/++ \\
+/++ \\
+/++\end{array}$ \\
\hline Acontia & Basitrichs 3 (C) & $\begin{array}{l}\text { A } \\
\text { B } \\
\text { C } \\
\text { D } \\
\text { A } \\
\text { B } \\
\text { C } \\
\text { D }\end{array}$ & $\begin{array}{l}(43.5-54.0) \times(4.1-4.9) \\
(44.3-54.1) \times(4.1-5.7) \\
(47.6-57.4) \times(4.9-5.7) \\
(41.0-48.4) \times(4.1-4.9) \\
(13.0-19.7) \times(1.6-2.5) \\
(15.6-21.2) \times(1.6-2.5) \\
(15.6-18.7) \times(1.6-2.5) \\
(18.0-21.2) \times 2.5\end{array}$ & $\begin{array}{r}20 \\
20 \\
20 \\
20 \\
20 \\
12 \\
8 \\
9\end{array}$ & $\begin{array}{l}+++ \\
+++ \\
+++ \\
+++ \\
+ \\
+/-- \\
+1-- \\
+1--\end{array}$ \\
\hline
\end{tabular}

fied and mostly in center of mesogloea (Fig. 4B). Longitudinal tentacle musculature ectodermal.

Column wall of similar thickness entire length. Mesogloea $0.10-0.58 \mathrm{~mm}$ thick, $1.56-2.92 \mathrm{~mm}$ at tubercles level; epidermis $0.03-0.10 \mathrm{~mm}$ thick, and gastrodermis 0.02-0.05 mm thick. Cuticle about 4-10 $\mu \mathrm{m}$ thick.
Cnidom. Spirocysts, basitrichs, and microbasic p-mastigophores. A survey of the cnidom is presented in Table 1 and Figure 5.

Colour. Oral disc and tentacles whitish in living material. White marks around mouth cone, and tentacles of fourth 

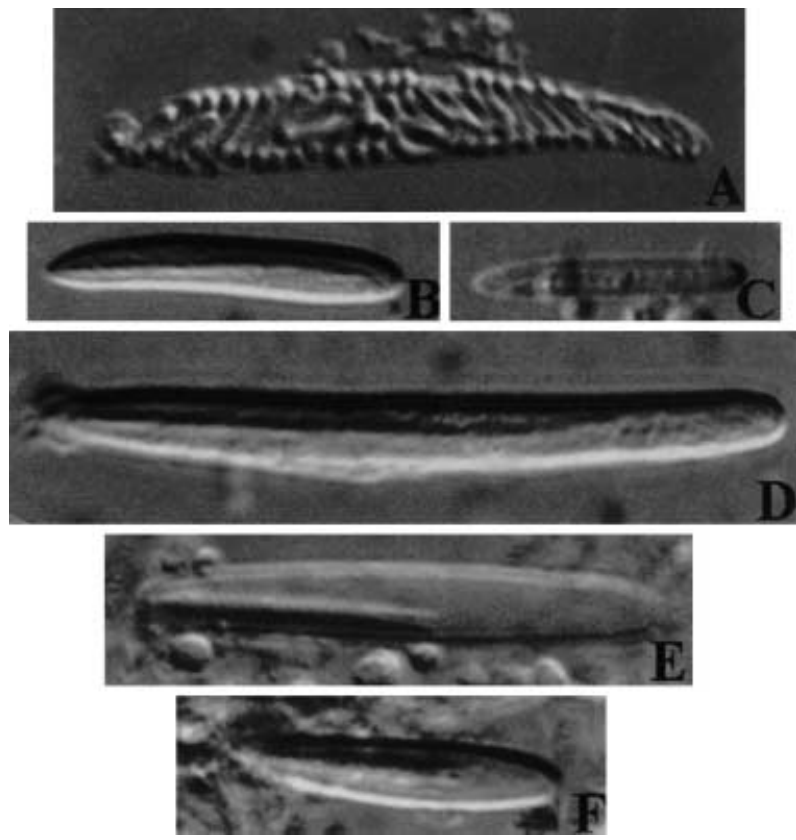

Fig. 5 Hormathia armata, sp. nov. Cnidom. (A) Spirocyst; (B) basitrich 2; (C) basitrich 3; (D) basitrich 1; (E) microbasic p-mastigophore 1; (F) microbasic p-mastigophore 2. See text and Table I for explanation

cycle with white V-shaped marks at base on oral side (Fig. 1A). Tentacles of the last cycles with small white marks at base on aboral side (Fig. 1B). Oral disc and tentacles brownish or yellowish in preserved material. Column and base of living and preserved material dirty brown or yellowish because of cuticle and foreign particles.

Geographic and depth distribution. Hormathia armata sp. nov. has been found only in the eastern Weddell Sea between 65 and $444 \mathrm{~m}$, although most specimens were collected between 234 and $444 \mathrm{~m}$.

Etymology. The specific name armata (armed in Latin) refers to the crown of flattened and hooked tubercles at the distal end of the scapus, a diagnosis feature of Hormathia armata sp. nov.

\section{Discussion}

Hormathia armata sp. nov. is compared here to the most similar species of Hormathia from the southern hemisphere, $H$. pectinata and $H$. spinosa.

Hormathia pectinata was described by Hertwig (1882a, 1882b) from a single specimen deposited in the NHM (Figs. 6 A, B; Table 2). Additional specimens from different localities were studied by McMurrich (1893), Carlgren (1959) and Riemann-Zürneck (1973). The most remarkable features of $H$. pectinata are its coronal row of tubercles in the distal part of the scapus and the cnidom, particularly the relatively short basitrichs in the acontia and pedal disc (Table 2).
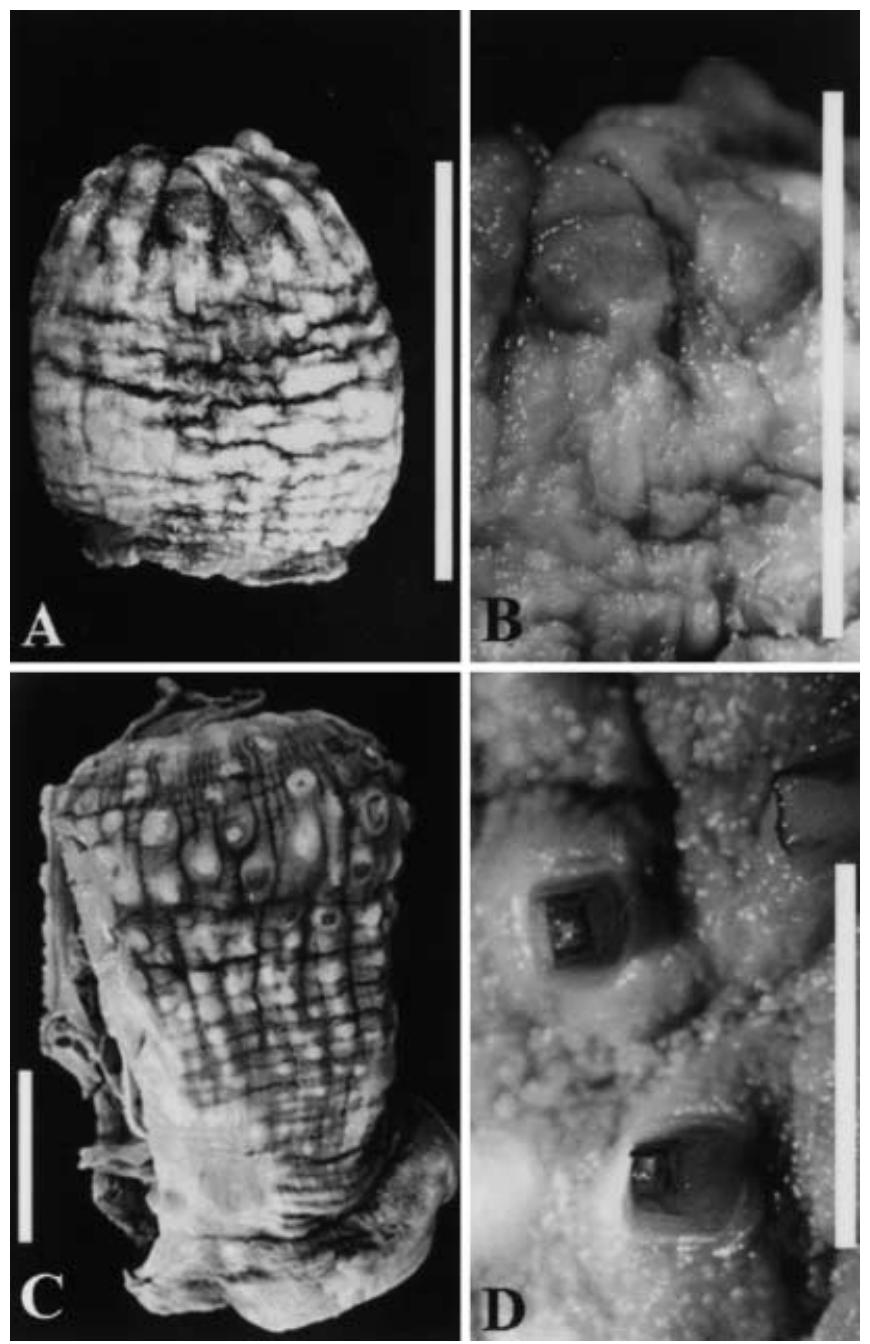

Fig. 6 Hormathia pectinata (Hertwig 1882) (Holotype, NHM 1889.11.25.18). (A) Lateral view of the column. (B) Detail of the rounded tubercles. Hormathia spinosa (Hertwig 1882) (Syntype, NHM 1890.7.23.1). (C) Lateral view of the column; note irregular arrangement of the tubercles on the scapus. (D) Detail of the pyramidal tubercles on hemispherical bases. Scale bars: A and C, $20 \mathrm{~mm}$; B and D, $5 \mathrm{~mm}$

Hormathia spinosa was collected during the Challenger expedition (Hertwig 1882a, 1882b) and, despite the precise description of external and internal anatomy, the type material has been re-examined (Figs. $6 \mathrm{C}$, D; Table 3).

The cnidom of the type material of Hormathia pectinata and $H$. spinosa is similar to that of other Hormathia species including spirocysts, basitrichs and microbasic p-mastigophores, although capsules of the last category have not been clearly detected in the filaments and stomodaeum where they are usually present. This is probably due to the preservation of this material. However, a complete view of the size ranges and distribution of the cnidae of $H$. pectinata based on specimens from both sides of Patagonia was reported by Riemann-Zürneck (1973). 
Table 2 Size ranges of the cnidae (in $\mu \mathrm{m}$ ) of Hormathia pectinata, holotype (NHM 1889.11.25.18). Frequency: $+++=$ very common, $++=$ common,$+=$ rather common, $--=$ sporadic. $\mathrm{N}=$ number of capsules measured.

\begin{tabular}{|c|c|c|c|c|}
\hline Body part & Nematocyst Type & $\begin{array}{l}\text { Range (in parentheses) of length and width } \\
\text { of nematocyst capsules in } \mu \mathrm{m}\end{array}$ & $\mathrm{N}$ & Frequency \\
\hline Pedal disc & Basitrichs & $(17.1-22.0) \times 2.5$ & 6 & + \\
\hline Scapus & Basitrichs & $(22.0-27.9) \times(3.3-4.1)$ & 8 & + \\
\hline Scapulus & Basitrichs & $(18.9-27.1) \times(2.5-3.3)$ & 6 & + \\
\hline Tentacles & $\begin{array}{l}\text { Spirocysts } \\
\text { Basitrichs } \\
\text { Basitrichs }\end{array}$ & $\begin{array}{l}(16.4-32.8) \times(2.5-5.7) \\
(21.2-27.1) \times(2.5-3.3) \\
(9.7-11.5) \times(1.6-2.5)\end{array}$ & $\begin{array}{r}20 \\
20 \\
6\end{array}$ & $\begin{array}{l}+/++ \\
++ \\
--\end{array}$ \\
\hline Stomodaeum & Basitrichs & $(29.4-34.3) \times(3.3-4.1)$ & 20 & ++ \\
\hline Filaments & $\begin{array}{l}\text { Basitrichs } \\
\text { Microbasic } \\
\text { p-mastigophores? }\end{array}$ & $\begin{array}{l}(17.2-21.3) \times(3.3-4.1) \\
(16.4-19.7) \times(3.3-4.1)\end{array}$ & $\begin{array}{l}20 \\
12\end{array}$ & $\begin{array}{l}++ \\
+\end{array}$ \\
\hline Acontia & Basitrichs & $(29.5-34.3) \times 3.3$ & 20 & +++ \\
\hline
\end{tabular}

Table 3 Size ranges of the cnidae (in $\mu \mathrm{m}$ ) of Hormathia spinosa, syntype (NHM 1890.7.23.1). Frequency: +++ = very common, $++=$ common,$+=$ rather common, $--=$ sporadic. $\mathrm{N}=$ number of capsules measured

\begin{tabular}{|c|c|c|c|c|}
\hline Body part & Nematocyst Type & $\begin{array}{l}\text { Range (in parentheses) of length and width } \\
\text { of nematocyst capsules in } \mu \mathrm{m}\end{array}$ & $\mathrm{N}$ & Frequency \\
\hline Pedal disc & Basitrichs & $(31.2-39.4) \times(3.3-4.1)$ & 20 & ++ \\
\hline Scapus & $\begin{array}{l}\text { Basitrichs } \\
\text { Basitrichs }\end{array}$ & $\begin{array}{l}(27.9-33.6) \times 4.1 \\
14.8 \times(1.6-2.5)\end{array}$ & $\begin{array}{r}20 \\
3\end{array}$ & $\begin{array}{l}++ \\
--\end{array}$ \\
\hline Scapulus & Basitrichs & $(31.2-38.5) \times(3.3-4.9)$ & 20 & ++ \\
\hline Tentacles & $\begin{array}{l}\text { Spirocysts } \\
\text { Basitrichs }\end{array}$ & $\begin{array}{l}(41.0-65.6) \times(3.3-7.4) \\
(35.3-38.5) \times(2.5-3.3)\end{array}$ & $\begin{array}{r}20 \\
7\end{array}$ & $\begin{array}{l}++ \\
+\end{array}$ \\
\hline Stomodaeum & Basitrichs & $(32.8-41.8) \times(3.3-4.9)$ & 20 & ++ \\
\hline Filaments & $\begin{array}{l}\text { Basitrichs } \\
\text { Basitrichs } \\
\text { Microbasic } \\
\text { p-mastigophores? }\end{array}$ & $\begin{array}{l}(40.2-43.5) \times(3.3-4.1) \\
(27.9-35.3) \times(4.1-4.9) \\
(30.2-36.1) \times(4.1-4.9)\end{array}$ & $\begin{array}{r}11 \\
20 \\
5\end{array}$ & $\begin{array}{l}+ \\
++ \\
--\end{array}$ \\
\hline Acontia & Basitrichs & $(41.8-49.2) \times(3.3-4.1)$ & 20 & +++ \\
\hline
\end{tabular}

Hormathia pectinata and $H$. spinosa share with $H$. armata sp. nov. the pointed tubercles that cover at least the distal half of the scapus. H. pectinata shows these tubercles only at the end of twelve longitudinal combs, in the most distal part of the scapus. However, in $H$. armata sp. nov. and $H$. spinosa, the tubercles are distributed along the scapus, although they are more conspicuous and prominent on the distal third of the column. The tubercles are regularly arranged in $H$. armata sp. nov., but they are irregularly distributed in $H$. spinosa.

Although the tubercles of Hormathia armata sp. nov. and $H$. spinosa are pyramidal, their bases are different in shape, being hemispherical in H. spinosa (Fig. $6 \mathrm{D}$ ) and square in $H$. armata sp. nov. (Fig. 3 B). In H. pectinata, the pointed tubercles are rounded or slightly digitiform (see Fig. 6B; and McMurrich 1893: plate XXXII, fig. 98).

A diagnostic feature of Hormathia armata sp. nov. is the crown of longitudinally flattened and hooked tubercles, usually twelve, at the distal part of the scapus.
While this crown is very conspicuous in $H$. armata $\mathrm{sp}$. nov. (Fig. 3A, B), it is absent in H. pectinata (Fig. 6A) and $H$. spinosa (Fig. 6C).

The size ranges and distribution of the cnidae offer additional characters that distinguish the three species (Tables 1, 2, 3). Hormathia pectinata can be easily separated from $H$. armata sp. nov. and $H$. spinosa by its shorter basitrichs in the acontia, although RiemannZürneck (1973) found specimens from Argentinean coast with longer basitrichs as is usual in specimens of the Chilean coast (the type locality). Furthermore, the longest basitrichs (see Fig. 5 D), shared by H. armata sp. nov. and $H$. spinosa in the filaments, are absent in $H$. pectinata. $H$. spinosa has longer basitrichs in the scapulus, which clearly set it apart from the other two species. The basitrichs from the pedal disc of $H$. armata sp. nov. are longer than those observed for $H$. pectinata and shorter than those of $H$. spinosa. Finally, from the four studied specimens of $H$. armata sp. nov. (Table 1), only one had microbasic p-mastigophores in the 
scapulus. This could be considered as singular, but the sporadic occurrence of this type of nematocyst in the column has been observed in other Hormathia species (Riemann-Zürneck 1973, 1994; den Hartog 1977).

Hormathia spinosa is considered present in subantarctic areas and off eastern Japan (Hertwig, 1882a, $1882 \mathrm{~b}), \mathrm{H}$. pectinata has been found in both sides of Patagonia (Hertwig, 1882a, 1882b; McMurrich 1893; Carlgren 1959; Riemann-Zürneck 1973) and H. armata sp. nov. is known only from the eastern Weddell Sea. Voß (1998), studying the distribution of the macrozoobenthic communities in eastern Weddell Sea, established the limit of shelf community to $530 \mathrm{~m}$ depth. Thus, we could consider $H$. armata sp. nov. as a shelf sea anemone (65-444 $\mathrm{m}$ in depth), whereas $H$. spinosa and $H$. pectinata have been reported from abyssal $(2812-2925 \mathrm{~m})$ and bathyal waters $(405-1220 \mathrm{~m}$ in depth) respectively.

Acknowledgements We thank Daphne G. Fautin (University of Kansas, USA) for her kind assistance during the elaboration of the present work. Special thanks go to Josep Maria Gili (Instituto de Ciencias del Mar, Barcelona) and Wolf Arntz (Alfred Wegener Institute, Bremerhaven) who made possible the participation in the Antarctic cruises where the present material was collected.

Sheila Halsey (Natural History Museum, London) provided the loan of the type material of $H$. pectinata and $H$. spinosa from the Challenger Expedition. The authors acknowledge the helpful assistance of the Department of Cellular Biology of the University of Seville for use the histological equipment. The authors acknowledge the valuable assistance of the officers and crew of the R/V Polarstern, and many colleagues on board during the EASIZ-II and EASIZ-III cruises. Support was provided by CICYT grants, ANT97-1533-E, ANT98-1739-E, and ANT991608-E.

\section{References}

Carlgren O (1927) Actiniaria and Zoantharia. Further Zool Res Swed Ant Exp 1901-1903, 2(3): 1-102

Carlgren O (1928) Actiniaria der Deutschen Tiefsee-Expedition. Wissen Ergeb Deutschen Tiefseen-Exp 1898-1899, 22(4): $123-266$

Carlgren O (1949) A survey of the Ptychodactiaria, Corallimorpharia and Actiniaria. K. Svenska Vetenskapsakad Handl, ser 4, 1(1): $1-121$

Carlgren O (1959) Corallimorpharia and Actiniaria with description of a new genus and species from Peru. Rep Lund Univ Chile Exp 1948-49, 38: 2-38
Fautin DG, Barber BR (1999) Maractis rimicarivora, a new genus of sea anemone (Cnidaria: Anthozoa: Actiniaria: Actinostolidae) from an Atlantic hydrothermal vent. Proc Biol Soc Wash 112(3): 624-631

Fautin-Dunn D (1983) Some Antarctic and Sub-Antarctic Sea Anemones (Coelenterata: Ptychodactiaria and Actiniaria). Biology of the Antarctic Seas XIV, Ant Res Ser, 39: 1-67. AGU, Washington, D. C.

Gabe M (1968) Technique Histologique. Massou et Cie, Paris

Grebelnyi SD (1980a) On the northern representatives of the genus Hormathia (Hormathiidae, Actiniaria). Issledovanija Fauny Morej 25: 12-28 (In Russian)

Grebelnyi SD (1980b) Distribution of sea anemones in the Arctic.In O. A. Skarlato (Ed): The teorethical and practical importance of the coelenterates 20-33. Aca Sci USSR Zool Ins (In Russian)

Hartog JC den (1977) Notes on the little known sea anemone $\mathrm{Ca}$ taphellia brodricii and the closely allied Hormathia coronata and Paraphellia expansa (Actiniaria, Hormathiidae). Nederl J Zool 27(3): 237-244

Hertwig R (1882a) Die Actinien der Challengerexpedition. Gustav Fischer, Jena. pp 1-119

Hertwig R (1882b) Report on the Actiniaria dredged by H.M.S. Challenger during the years 1873-1876. Sci Res Voy H.M.S. Challenger, Zoology, 6(1): 1-136

Johansen DA (1940) Plant microtechniques. McGraw-Hill. New York \& London

Longhurst A (1998) Ecological Geography of the Sea. Academic Press, San Diego

Manuel RL (1988) British Anthozoa. Kermack DM, Barnes RSK (eds) Synopses of the British Fauna (new series) $\mathrm{N}^{\circ} 18$ (Revised). Brill EJ/Backhuys DrW Leiden, New York, København, Köln

McMurrich JP (1893) Report on the Actiniae collected by the United States Fish Commission Steamer Albatross during the winter of 1887-1888. Proc U S Nat Mus 16 (930): 119-216

McMurrich JP (1904) The Actiniae of the Plate Collection (in Plate Fauna Chilensis 3. 2). Zool Jahrb Jena Suppl 6(2): 215-306

Riemann-Zürneck K (1973) Actiniaria des Südwestatlantik. I. Hormathiidae. Helgol wiss Meeres 25: 273-325

Riemann-Zürneck K (1994) Taxonomy and ecological aspects of the subarctic sea anemones Hormathia digitata, Hormathia nodosa and Allantactis parasitica (Coelenterata, Actianiaria). Ophellia 39(3): 197-224

Stephenson TA (1918) Coelenterata. I. Actiniaria. Nat Hist Rep Brit Ant ("Terra Nova") Exp 1910, 5(1): 1-68

Stephenson TA (1920) On the classification of Actiniaria. I. Q J Microsc Sci, n s 64 (256): 425-574

Stephenson TA (1935) The British sea anemones. Ray Soc, London 2: $1-426$

Tur JM (1993) Redescription and biological aspects of Hormathia alba (Andres, 1881), a luminescent sea anemone (Anthozoa, Actiniaria). Helgol Meeres 47: 213-21

Voß J (1998) Zoogeographie und Gemeinschaftsanalyse des Makrozoobenthos des Weddellmeeres (Antarktis). Ber Polarforsch 45: 1-144 